\title{
SUDDEN CARDIAC DEATH IN HAEMODIALYSIS PATIENTS - ASSESSMENT OF RISK FACTORS AND PREVENTION
}

Dejan Petrović ${ }^{1}$, Jasna Trbojević-Stanković ${ }^{2}$, Vesna Stojanovic-Marjanovic ${ }^{3}$, Aleksandra Nikolic ${ }^{3}$, Vladimir Miloradovic ${ }^{4}$ ${ }^{1}$ Clinic for Urology and Nephrology, Clinical Center "Kragujevac", Kragujevac

${ }^{2}$ Department of Hemodialysis, Clinical Hospital Center “Dragiša Mišović”, Belgrade ${ }^{3}$ Clinic for Internal Medicine, Clinical Center "Kragujevac", Kragujevac

${ }^{4}$ Clinic for Cardiology, Clinical Center "Kragujevac", Kragujevac, Serbia

\section{IZNENADNA SRČANA SMRT BOLESNIKA NA HEMODIJALIZI: PROCENA RIZIKA I PREVENCIJA \\ Dejan Petrović ${ }^{1}$ Jasna Trbojević-Stanković ${ }^{2}$ Vesna Stojanović-Marjanovićs ${ }^{3}$ Aleksandra Nikolić3 Vladimir Miloradović ${ }^{4}$ \\ ${ }^{1}$ Klinika za urologiju i nefrologiju, KC „Kragujevac“, Kragujevac \\ ${ }^{2}$ Odeljenje hemodijalize, KBC „Dragiša Mišović“, Beograd \\ ${ }^{3}$ Klinika za internu medicinu, KC „Kragujevac“, Kragujevac \\ ${ }^{4}$ Klinika za kardiologiju, KC „Kragujevac“, Kragujevac, Srbija}

Received / Primljen: 24.03.2013.

Accepted / Prihvaćen: 2.04.2013

\section{ABSTRACT}

Haemodialysis patients are at high risk for sudden cardiac death (SCD), with the annual mortality rate from $S C D$ ranging from 5-7\%. The risk factors for SCD on haemodialysis include left ventricular remodelling, coronary disease, heart failure, rapid electrolyte and fluid shifts during dialysis sessions and secondary hyperparathyroidism. Echocardiography and standard electrocardiography can help identify patients at risk for SCD. The strategy for preventing SCD in haemodialysis patients includes primary (medicamentous treatment and adjusting dialysis parameters) and secondary (coronary revascularisation and placement of cardioverter defibrillator) treatment planning.

Key words: sudden cardiac death, haemodialysis, treatment plan

\section{INTRODUCTION}

Sudden cardiac death (SCD) is unexpected death due to cardiac causes occurring within one hour of symptom onset (1). Although the most frequent cause of SCD is coronary artery disease, other contributing factors in maintenance haemodialysis (HD) patients include left ventricular remodelling, volume overload, disturbed electrolyte balance, rapid electrolyte and fluid shifts and secondary hyperparathyroidism $(1,2)$. The annual mortality rate from SCD in HD patients is $5-7 \%$ (2).

\section{Aetiopathogenesis of sudden cardiac death}

Risk factors and cardiovascular diseases

Uraemia in general and HD in particular carry numerous risk factors for the development of cardiovascular disease. These include high arterial blood pressure, multiple

\section{SAŽETAK}

Bolesnici kojiseleče ponavljanim hemodijalizama imajuvisok rizik od iznenadne srčane smrti. Jednogodišnja stopa iznenadne srčane smrti kod ovih bolesnika iznosi 5-7\%. U faktore rizika za nastanakiznenadne srčane smrti spadaju: preoblikovanjeleve komore srca, koronarna arterijska bolest, srčana slabost, brza izmena elektrolita $i$ tečnosti u toku seanse hemodijalize, i sekundarni hiperparatireoidizam. Ehokardiografija i standardna elektrokardiografija omogućavaju izdvajanje bolesnika koji imaju povećan rizik od iznenadne srčane smrti. Strategija za sprečavanje nastanka iznenadne srčane smrti kod bolesnika koji se leče ponavljanim hemodijalizama sastoji se u primeni primarnog $i$ sekundarnog plana lečenja. Primarni plan lečenja uključuje medikamente $i$ prilagodavanje uslova hemodijalize bolesniku, dok sekundarni plan lečenja uključuje revaskularizaciju koronarnih arterija $i$ ugradnju implantabilnog kardioverter defibrilatora.

Ključne reči: iznenadna srčana smrt, faktori rizika, hemodijaliza, plan lečenja

lipid abnormalities, oxidative stress, microinflammation, hyperhomocysteinaemia, anaemia, high shunt blood flow and secondary hyperparathyroidism (3-5). All these factors are responsible for the development of atherosclerosis, arteriosclerosis and cardiomyopathy (5).

Atherosclerosis occurs when fatty plaques build up in the intimal layer of arterial walls, narrowing the lumen of the vessel. Atherosclerosis of the coronary arteries causes ischaemic heart disease (6). Arteriosclerosis is a condition in which the artery wall thickens due to media thickening, calcification and remodelling of the smooth muscle cells of the tunica media into osteoblasts-like cells. Hardening of the arterial walls in arteriosclerosis decreases their elasticity and causes pressure overload to the left ventricle (3-7). Cardiomyopathy occurs due to left ventricular pressure and/or volume overload, which causes left ventricular wall thickening, decreased myocardial vasculari- 
sation, myocardial scarring and alterations of the small blood vessels in the myocardial interstitium. Clinical manifestations of cardiomyopathy include heart failure, myocardial hypersensitivity to ischaemia, prolonged ventricular repolarisation (prolonged QT interval), increased risk for ventricular arrhythmias and $\operatorname{SCD}(5,8,9)$. Left ventricular hypertrophy, coronary artery disease and disturbed systolic function of the left ventricle (left ventricular ejection fraction $<35 \%$ ) represent major risk factors for SCD in maintenance HD patients $(5,8,9)$.

\section{Risk factors for sudden cardiac death related to haemodialysis}

\section{Rapid electrolyte shift}

Haemodialysis per se is a risk factor for arrhythmias due to rapid the electrolyte shifts and cardiovascular instability (intradialytic hypotension) that can occur with this treatment (10-13). Rapid potassium and calcium shifts during HD sessions and low levels of electrolytes in the dialysate increase the risk for cardiac arrhythmia (10-13). The use of potassium-free or low-potassium dialysates $\left(\left[\mathrm{K}^{+}\right] \mathrm{d}=1.0\right.$ $\mathrm{mmol} / \mathrm{L}$ ), particularly at the beginning of a dialysis session, removes potassium quickly, causing a rapid decline in the patient's serum potassium concentration, which may lead to a disturbance of ventricular myocardial repolarisation, an increase in the corrected QTc interval (QTd) dispersion and increased risk for ventricular arrhythmias (10-13).

Calcium ions, however, play an important role in myocardial and arterial contractility. The use of low-calcium $\left(\left[\mathrm{Ca}^{2+}\right]=1.25 \mathrm{mmol} / \mathrm{L}\right)$ dialysates decreases ionised serum calcium and prolongs and increases the dispersion of the QTc interval, thus contributing to ventricular arrhythmias and SCD (10-13).

Educating patients to maintain an optimum predialysis potassium level of 4.6-5.3 $\mathrm{mmol} / \mathrm{L}$ and individual adjustment of dialysis parameters decreases the risk of SCD death in HD patients (13).

\section{Rapid fluid shifts (haemodynamic instability)}

Dialysis-induced hypotension is represented by a sudden drop of systolic blood pressure below $90 \mathrm{mmHg}$ or of at least $30 \mathrm{mmHg}$ during $\mathrm{HD}(13,14)$. Acute intradialytic hypotension reduces coronary blood flow and may lead to myocardial ischaemia, disturbances of regional myocardial motility and ventricular arrhythmia even in the absence of coronary heart disease (15). Haemodynamic instability during HD sessions can be prevented by the early identification of patients at higher risk for hypotension and by the individual adjustment of dialysis parameters. Patients at risk are those with malnutrition and hypoalbuminaemia, left ventricular hypertrophy, diabetes and diseases of the autonomous nervous system. Individualised dialysis strategies to obtain haemodynamic stability include the adequate choice of dialysers, adjusting the dialysate temperature, the use of sodium-modelling profiles, the careful adjustment of ultrafiltration and sequential dialysis (13-15).
Interdialytic restriction of fluid and dietary sodium intake (recommended maximum intake $2.0 \mathrm{~g} / 24 \mathrm{~h}$ ) and an interdialytic weight gain of less than $4 \%$ of the dry body weight decrease left ventricular overload, haemodynamic stress and the risk for ventricular arrhythmias (16).

\section{Identifying patients at risk for sudden cardiac death}

All HD patients have increased risk for SCD (17-19). The plan for the early detection of patients at risk for SCD should include the following: clinical assessment of the patient (anamnesis and physical examination), echocardiographic examination (measuring QT/QTc interval, measurement of QTc interval dispersion, variation of $\mathrm{T}$ wave amplitude and duration), measuring heart rate variability (HRV) and determining serum troponin $\mathrm{T}$ and troponin I concentrations (20-24).

The QT interval is easily measured and enables the identification of patients at higher risk for SCD. The QT interval is a measure of the time between the start of the $Q$ wave and the end of the $T$ wave on an electrocardiogram (ECG). It represents the time required for the completion of both ventricular depolarisation and repolarisation. The standard clinical correction is to use Bazett's formula to calculate the heart rate-corrected QT interval. Bazett's formula is QTc $=Q T / \sqrt{R R}$, where $\mathrm{RR}$ is the interval from the onset of one QRS complex to the onset of the next QRS complex, measured in milliseconds. In HD patients, a QTc interval longer than $500 \mathrm{~ms}$ suggests an increased risk for ventricular dysrhythmia $(24,25)$. Furthermore, increased QTc dispersion, as measured on standard ECG, is a useful and reliable predictor of susceptibility to life-threatening ventricular arrhythmias in HD patients. QTc interval variability is the difference between the longest and the shortest QTc interval registered on a standard ECG $(25,26)$; normal QTc variability is 40 - $50 \mathrm{~ms}$. QTc variability over $50 \mathrm{~ms}$ in HD patients suggests higher risk for ventricular arrhythmias and SCD (26).

Heart rate variability is an electrocardiographic parameter of sympathetic and parasympathetic control of the heart rate. A decrease or loss of HRV is associated with increased risk for ventricular arrhythmias and SCD (27, 28 ). Drugs that induce parasympathetic activity also decrease the rate of SCD in HD patients. ACE inhibitors and beta-blockers enhance the parasympathetic influence on the heart, increase HRV and decrease the risk for SCD in HD patients $(27,28)$. Nocturnal HD, performed for 8 to 10 hours, 6 times/week, decreases sympathetic activity and increases HRV and the partial pressure of arterial blood overnight compared to the standard HD scheme of 3 times for 4 hours each week (20).

\section{Treatment plan}

The plan to reduce the risk for SCD in maintenance HD patients includes primary and secondary measures (29-32). The primary plan requires medicamentous therapy and 
individual adjustment of HD parameters, while secondary intervention includes coronary revascularisation and the placement of an implantable cardioverter defibrillator (ICD) (29-32).

\section{Primary treatment plan}

\section{Medicamentous therapy}

Medicamentous therapy to control risk factors for SCD in maintenance HD patients includes beta-blockers, angiotensin convertase inhibitors, angiotensin receptor blockers, vitamin $\mathrm{D}$ active metabolites, calcimimetics and erythropoietin. Beta-blockers decrease the risk for SCD in HD patients by decreasing myocardial sympathetic activity, lowering the rate of ventricular arrhythmias and increasing HRV and baroreceptor sensitivity (28-33). Carvedilol improves left ventricular ejection fraction and survival in heart failure patients with NYHA II and NYHA III on maintenance HD $(34,35)$. Other treatments are focused on increasing HRV (beta-blockers, angiotensin convertase inhibitors), stabilising arteriosclerotic plaques (anti-aggregation agents and statins) and controlling left ventricular hypertrophy (beta-blockers, angiotensin convertase blockers and erythropoietin) (28-33).

\section{Haemodialysis treatment}

A biocompatible high-flux membrane, ultrapure dialysate (bacteria $<0.1 \mathrm{CFU} / \mathrm{mL}$ and endotoxin $<0.03 \mathrm{EU} / \mathrm{mL}$ ) and an optimal dialysis dose $(\mathrm{Kt} / \mathrm{V} \geq 1.4)$ significantly contribute to lowering the mortality rate in HD patients (34). Haemodiafiltration (HDF) achieves optimal transfer for both small $(<5$ $\mathrm{kDa}$ ) and mid-size (5-50 kDa) molecules, including mediators of inflammation, complement factor D and other molecules involved in the development of heart disease (36). The optimal treatment with standard HD or HDF ( $\geq 3$ times per week for $\geq 4 \mathrm{~h}$ ), with blood flow $\geq 300 \mathrm{~mL} / \mathrm{min}$, adequate dietary intake, interdialysis weight gain $<4 \%$ and adequate medicamentous treatment (phosphate binders, vitamin D active metabolites, calcimimetics, iron supplements and erythropoietin), should provide a $\mathrm{Kt} / \mathrm{V} \geq 1.4$, mean arterial pressure $\leq 105$ $\mathrm{mmHg}$, predialysis serum potassium concentration of 4.6-5.3 $\mathrm{mmol} / \mathrm{L}$, serum phosphate concentration of 0.8-1.6 mmol/L, serum calcium concentration of $2.2-2.5 \mathrm{mmol} / \mathrm{L}$, solubility product $\leq 4.4 \mathrm{mmol}^{2} / \mathrm{L}^{2}$, parathormone levels of $150-300 \mathrm{pg} /$ $\mathrm{mL}$, bicarbonate level $\geq 20 \mathrm{mmol} / \mathrm{L}$, transferrin saturation of 30-50\%, serum ferritin concentration of 200-500 ng/mL, haemoglobin concentration of $100-120 \mathrm{~g} / \mathrm{L}$ and serum albumin concentration $\geq 35 \mathrm{~g} / \mathrm{L}$ (37).

In patients with disturbed left ventricular systolic function, hypotension and haemodynamic instability limit the achievement of optimal ultrafiltration during an HD session. These patients are candidates for peritoneal dialysis because it provides better haemodynamic stability (38). The treatment plan for haemodynamically unstable patients should also include some of the new HD modalities, such as short daily haemodialysis (SDHD) or nocturnal home hae- modialysis (NHD). SDHD is performed 5 to 6 days per week for 1.5-2 hours, whereas NHD is performed while sleeping, usually for 6-8 hours, 4-6 nights per week (38).

\section{Secondary treatment plan}

\section{Coronary revascularisation}

According to coronarographic findings, HD patients are at either high risk (coronary disease of the main left ventricular artery; three-vessel coronary disease, mild symptoms and decreased left ventricular function; two-vessel disease involving the proximal left coronary artery) or low risk for acute coronary syndrome (single-vessel coronary disease - only one vessel involved and preserved myocardial function) $(6,39,40)$. Coronary artery bypass grafting (CABG) decreases the risk of acute coronary syndrome in the high-risk group, whereas patients at low risk are usually treated with drugs, percutaneous transluminal angioplasty (PTCA) or coronary artery stenting (CAS) $(6,39,40)$. HD patients have a significantly higher inhospital mortality rate in the first 30 days following CABG and are at significantly higher risk for postoperative complications (sepsis, respiratory insufficiency and gastrointestinal complications) compared to HD patients after CAS and nonrenal patients $(41,42)$. More studies are needed to determine the criteria for selecting HD patients and adequate coronary revascularisation procedures $(41,42)$.

\section{Implantable cardioverter defibrillator}

ICDs decrease mortality risk by $42 \%$ in HD patients surviving cardiac arrest $(19,23,43)$. However, only $8 \%$ of maintenance HD patients who survive cardiac arrest actually have preventively placed ICDs $(19,23,42)$. ICD implantation is associated with a high risk of bleeding, infection and venous subocclusion and occlusion. Therefore, it is typically placed on the side opposite to the vascular access for HD (43). ICDs are placed in HD patients with a left ventricular ejection fraction $<35 \%$ following cardiac arrest caused by ventricular dysrhythmias (ventricular tachycardia or fibrillation). More clinical studies are needed to define the criteria for choosing patients for this procedure and to assess its validity, cost-effectiveness and budget impact in a manner similar to other health technologies (43-47).

\section{CASE REPORT}

Patient CR, born in 1955, started regular haemodialysis therapy in 1994. (Insuffitientia renalis chronica terminalis, Status post-nephrectomiam lat.dex. pp calculosis, Haemodialysis chronica regularis). As a part of uncontrolled secondary hyperparathyroidism (Secondary hyperparathyroidism, Osteodystrophia chronica renalis, $i P T H=1500 \mathrm{pg} / \mathrm{ml})$, the patient developed significant vascular (coronary artery) and 
valvular calcification, which called for triple aortocoronary by-pass and implantation of a synthetic mitral valve (Status post-IM inferolateralis aa III, Status post-by-pass AC triplex et implantationem valvulae mitralis aa III). The patient received regular haemodialysis therapy, erythropoietin, statins and antiaggregation and anticoagulant therapy with adequate laboratory monitoring. Sudden and rapid deterioration of chronic heart insufficiency (Myocardiopathia chronica ischaemica decompensata) and the development of cardiogenic shock (Shock cardiogenes) resulted in the patient's death (Exitus letalis).

\section{CONCLUSION}

Early identification of maintenance HD patients at risk of ventricular dysrhythmias and SCD enables timely and adequate treatment to decrease the risk for SCD mortality and improve survival.

\section{ACKNOWLEDGMENTS}

The authors would like to express their deepest gratitude to the Serbian Ministry of Science and Technological Development for their Grant $\mathrm{N}^{0} 175014$, which was used as one of the sources to support the study financially.

\section{REFERENCES}

1. Green D, Roberts PR. Ventricular arrhythmias and sudden death in patients with chronic kidney disease. J Ren Care 2010; 36(Suppl 1): 54-60.

2. Herzog CA, Mangrum M, Passman R. Sudden Cardiac Death and Dialysis Patients. Semin Dial 2008; 21(4): 300-7.

3. Petrović D, Jagić N, Miloradović V, Stojimirović B. Non-tradicional risk factors for development of cardiovascular complications in haemodialysis patients. Ser $J$ Exp Clin Res 2009; 10(3): 95-102. (in Serbian)

4. Chue CD, Townend JN, Steeds RP, Ferro CJ. Arterial stiffness in chronic kidney disease: causes and consequences. Heart 2010; 96(11): 817-23.

5. Shamseddin MK, Parfrey PS. Sudden cardiac death in chronic kidney disease: epidemiology and prevention. Nat Rev Nephrol 2011; 7(3): 145-54.

6. Petrović D, Miloradović V, Poskurica M, Stojimirović B. Diagnostics and treatment of ishemic heart disease in hemodialysis patients. Vojnosanit Pregl 2009; 66(11): 897-903. (in Serbian)

7. Petrović D, Stojimirović B. Secondary hyperparathyroidism - risk factor for development of cardiovascular complications in patients on hemodialysis. Med Pregl 2010; LXIII(9-10): 674-80. (in Serbian)

8. Petrović D, Stojimirović B. Left ventricular hypertrophy in hemodialysis patients. Med Pregl 2008; LXI(7-8): 369-74. (in Serbian)
9. Petrović D, Miloradović V, Poskurica M, Stojimirović B. Heart failure in haemodialysis patients: evaluation and treatment. Srp Arh Celok Lek 2011; 139(3-4): 248-55. (in Serbian)

10. Beumi M, Coppolino G, Bolignano D, Sturiale A, Campo S, Buemi A, et al. Arrhythmias and Hemodialysis: Role of Potassium and New Diagnostic Tools. Ren Fail 2009; 31(1): 75-80.

11. Severi S, Grandi E, Pes C, Badiali F, Grandi F, Santoro A. Calcium and potassium changes during haemodialysis alter ventricular repolarization: in vivo and in silico analysis. Nephrol Dial Transplant 2008; 23(4): 1378-86.

12. Genovesi S, Dossi C, ViganoMR, Galbiati E, Prolo F, Stella A, et al. Electrolyte concentration during haemodialysis and QT interval prolongation in uraemic patients. Europace 2008; 10(6): 771-7.

13. Pun PH, Lehrich RW, Honecycutt EF, Herzog CA, Middleton JP. Modifiable risk factors associated with sudden cardiac arrest within hemodialysis clinics. Kidney Int 2011; 79(2): 218-27.

14. Santoro A. Cardiovascular dialysis instability and convective therapies. Hemodialysis Int 2006; 10(1): 51-5.

15. Burton JO, Korsheed S, Grundy BJ, McIntyre CW. Hemodialysis-Induced Left Ventricular Dysfunction Is Associated with an Increase in Ventricular Arrhythmias. Ren Fail 2008; 30(7): 701-9.

16. Lopez-Gomez JM, Villaverde M, Jofre R, et al. Interdialytic weight gain as a marker of blood pressure, nutrition, and survival in hemodialysis patients. Kidney Int 2005; 67(Suppl 93): 63-8.

17. Petrović D, Stojimirović B. Cardiovascular morbidity and mortality in hemodialysis patients - epidemiological analysis. Vojnosanit Pregl 2008; 65(12): 893-900. (in Serbian)

18. Petrović D, Obrenović R, Trbojević-Stanković J, MajkićSingh N, Stojimirović B. Cardiovascular mortality in hemodialysis patients: clinical and epidemiological analysis. J Med Biochem 2011; 30(4): 302-8. (in Serbian)

19. Petrović D, Obrenović R, Trbojević-Stanković J, MajkićSingh N, Stojimirović B. Hyperphosphatemia - the risk factor dor adverse outcome in maintenance hemodialysis patients. J Med Biochem 2012; 31(3): 239-45. (in Serbian)

20. Kanabay M, Afsar B, Goldsmith D, Covic A. Sudden Death in Hemodialysis: An Update. Blood Purif 2010; 30(2): 135-45.

21. Saravanan P, Davidson NC. Risk Assessment for Sudden Cardiac Death in Dialysis Patients. Circ Arrhythm Electrophysiol 2010; 3(5): 553-9.

22. Petrović D, Jagić N, Miloradović V, Stojimirović B. Clinical importance of biochemical markers of cardiac damage in hemodialysis patients. Ser J Exp Clin Res 2008; 9(1): 5-8. (in Serbian)

23. Petrović D, Stojimirović B. Cardiac troponins: outcome predictors in hemodialysis patients. J Artif Organs 2009; 12(4): 258-63.

24. Green D, Roberts PR, New DI, Kalra PA. Sudden Cardiac Death in Hemodialysis Patients: An In-Depth Review. Am J Kidney Dis 2011; 57(6): 921-9. 
25. Gussak I, Gussak HM. Sudden cardiac death in nephrology: focus on acquired long QT syndrome. Nephrol Dial Transplant 2007; 22(1): 12-4.

26. Wu V-C, Lin L-Y, Wu K-D. QT interval dispersion in dialysis patients. Nephrology 2005; 10(2): 109-12.

27. Ranpuria R, Hall M, Chan CT, Unruh M. Heart rate variability (HRV) in kidney failure: measurement and consequence of reduced HRV. Nephrol Dial Transplant 2008; 23(2): 444-9.

28. Chan CT, Levin NW, Chertow GM, Larive B, Schulman G, Kotanko P, and the Frequent Hemodialysis Network Daily Trial Group. Determinants of Cardiac Autonomic Dysfunction in ESRD. Clin J Am Soc Nephrol 2010; 5(10): 1821-7.

29. Furgeson SB, Chonchol M. $\beta$-Blockade in Chronic Dialysis Patients. Semin Dial 2008; 21(1): 43-8.

30. De Bie MK, van Dam B, Gaasbeek A, van Buren M, van Erven L, Bax JJ, et al. The current status of interventions aiming at reducing sudden cardiac death in dialysis patients. Eur Heart J 2009; 30(13): 1559-64.

31. Petrović D, Tirmenštajn-Janković B, Živanović M, Nikolić A, Poskurica M, Stojimirović B. Sudden cardiac death in patients on regular hemodialysis. Timoč Med Glas 2010; 35(1-2): 19-26. (in Serbian)

32. McCullough PA, Sandberg KR. Chronic Kidney Disease and Sudden Death: Strategies for Prevention. Blood Purif 2004; 22(1): 136-42.

33. Massy ZA, Kasiske BL. Prevention of cardiovascular complications in chronic renal disease. In: Cardiovascular Disease in End-stage Renal Failure. Loscalzo J, London GM, (eds). New York: The Oxford University Press; 2000: 463-81.

34. Cice G, Ferrara L, Benedetto AD, Russo PE, Marinelli G, Pavese F, et al. Dilated Cardiomyopathy in DialysisBenefical Effects of Carvedilol: A Double-Blind, PlaceboControlled Trial. J Am Coll Cardiol 2001; 37(2): 407-11.

35. Cice G, Ferrara L, D'Andrea A, D'Isa S, Benedetto AD, Cittadini A, Russo PE, et al. Carvedilol Increases TwoYear Survival in Dialysis Patients With Dilated Cardiomyopathy. J Am Coll Cardiol 2003; 41(9): 1438-44.

36. Herzog CA. Can We Prevent Sudden cardiac Death in Dialysis Patients? Clin J Am Soc Nephrol 2007; 2(3): 410-2.
37. Karkar A. Caring for Patients with CRF: Rewards and Benefits. Int J Nephrol 2011: ID 639840.

38. Sood MM, Pauly RP, Rigatto C, Komenda P. Left ventricular dysfunction in the haemodialysis population. NDT Plus 2008; 1(4): 199-205.

39. Williams ME. Coronary Revascularisation in Diabetic Chronic Kidney Disease/End-Stage Renal Disease: A Nephrologist's perspective. Clin J Am Soc Nephrol 2006; 1(2): 209-20.

40. Johnston N, Dargie H, Jardine A. Diagnosis and treatment of coronary artery disease in patients with chronic kidney disease. Heart 2008; 94(8): 1080-8.

41. Rahmanian PB, Adams DH, Castillo JG, Vassalotti J, Filsoufi F. Early and late outcome of cardiac surgery in dialysis-dependent patients: Single-center experience with 245 consecutive patients. J Thorac Cardiovasc Surg 2008; 135(4): 915-22.

42. Nevis IF, Mathew A, Novick RJ, Parikh CR, Devereaux PJ, Natarajan MK, Iansavichus AV, et al. Optimal Method of Coronary Revascularisation in Patients Receiving Dialysis: Systematic Review. Clin J Am Soc Nephrol 2009; 4(2): 369-78.

43. Ito I, Kono K, Shinbo G, Tadokoro K, Abe C, Takemura $\mathrm{N}$, et al. Implantable cardioverter defibrillator in maintenance hemodialysis patients with ventricular tachyarrhythmias: A single-center experience. Hemodialysis Int 2009; 13(1): 48-54.

44. Korantzopoulos P, Liu T, Li L, Goudevenos JA, Li G. Implantable cardioverter defibrillator therapy in chronic kidney disease: a meta-analysis. Europace 2009; 11(11): 1469-75.

45. Roberts PR, Green D. Arrhythmias in chronic kidney disease. Heart 2011; 97(9): 766-73.

46. Kanbay M, Solak Y, Covic A, Goldsmith D. Sudden Cardiac Death in Patients with Chronic Kidney Disease: Prevention Is the sine qua non. Kidney Blood Press Res 2011; 34(4): 269-76.

47. Janković SM. Rituximab for the treatment of rheumatiod arthritis patients with failure to the first biologic drug: Impact on Republic fund for health insurance in Serbia. Racionalna terapija 2013; 5(1):1-7. 